UDC 332.363

\title{
SCIENTIFIC AND METHODOLOGICAL PRINCIPLES OF LAND DISTRIBUTION (RE-DISTRIBUTION) ON THE BASIS OF DESIGNATED PURPOSES AND TYPES OF LAND USE
}

Dorosh Y., Doctor of Economics Sciences

e-mail: landukrainenaas@gmail.com

Land Management Institute of the

National Academy of Sciences of Ukraine

Dorosh O., Doctor of Economics Sciences

e-mail:dorosholgas@ukr.net

National University of Life and Environmental Sciences of Ukraine

Kharytonenko R., Candidate of Economic Sciences (Ph.D.)

e-mail: kharytonenkor@gmail.com

Land Management Institute of the

National Academy of Sciences of Ukraine

Dorosh A. post-graduate student

E-mail: doroshandriyl@ukr.net

Zastulka Illia-Oleksandr Yu. post-graduate student

E-mail: oleksandr_zastulka94@ukr.net

National University of Life and Environmental Sciences of Ukraine

The normative legal acts and scientific publications on the distribution (redistribution) of land by purpose and types of use are analyzed on the example of land uses of institutions and enterprises of the National Academy of Agrarian Sciences of Ukraine (hereinafter - NAAS). It is established that in the current legislation there is no type of documentation on land management, concerning the decision of questions of distribution (redistribution) of land by types of use. To take into account the specifics of land use by the NAAS institutions and enterprises, which have land plots, research fields, nurseries, valuable lands for scientific research, 
which should be taken into account when developing documentation on land management.

The necessity of introducing scientific justification for determining the purpose and type of use as a section in the land documentation documentation is proposed.

Keywords: land management, scientific justification, land distribution (redistribution), research land use.

Formulation of the problem. All land plots are qualitatively heterogeneous from one another in their natural properties, legal regime of use and ecosystem function.

Article 19 of the Land Code of Ukraine (hereinafter - LCU) provides for their rational use of land plots in the system of land resources by their main purpose into nine categories. Directly establishing and changing the purpose of a specific land plot is carried out on land management projects for their allocation in accordance with Article 20 of the Civil Code. Types of land use within certain categories of land are determined taking into account urban planning and land management documentation [1].

Agricultural lands have a special place among land categories because this land category is inextricably linked to its direct use as a means of production, the territory for the location of elements of industrial, scientific, social infrastructure, and where the land acts as a legal object.

Pursuant to Article 22 of the LC, "agricultural land shall be recognized as land granted for agricultural production, agricultural research and training activities, placement of appropriate production infrastructure, including infrastructure for wholesale markets of agricultural products, or intended for these purposes" [1].

The type of use of agricultural land is set out in Articles 31, 33-37 of the Criminal Code, which include: agricultural land, personal farming, hay and pasture, horticulture and horticulture [1].

Land use by institutions and enterprises of the National Academy of Agrarian Sciences of Ukraine (hereinafter - NAAS) has a considerable number of land plots. 
By land category, they belong to agricultural land with intended use for research and educational purposes.

However, the land use of NAAS institutions and enterprises has a wider use of land to which they include: research fields, including fields of long-term experience, areas of organic agriculture, berries, nurseries, areas of elite seeds and planting material, areas with particularly valuable soils, objects the nature reserve, cultural heritage sites, including those included in the UNESCO Register, historical and cultural complexes, quarantine zones, economic areas of the experimental fields, etc.

The purpose of the article. Given the lack and inconsistency of the mechanism for the distribution (redistribution) of land by types of use in the existing land legislation, there is a need to investigate this issue and to make specific proposals for solutions on the example of land use by NAAS institutions and enterprises.

Analysis of recent research and publications. A considerable number of scientific researches of well-known scientists of land managers and economists are devoted to the research of the issue of works on the distribution (redistribution) of land by purpose and types of use in the system of agricultural land uses: L. Novakovsky, Y. Dorosh, O. Dorosh, A. Tretyak, V. Tretyak, V. Krivov, M. Stetsyuk and others. They proposed to solve problems in the legislative and production plan when developing land management documentation for agricultural land uses.

Today it is necessary to investigate the concepts of land use and their distribution (redistribution) in land management documentation.

Results of the study and discussion. As noted earlier, all land for their economic use is divided into categories, purpose and type of use within a certain category in accordance with the GCC. To understand this, it is necessary to define the term: land category, purpose, type of use. Land category means the division of land by their main purpose, which is enshrined in Ukraine by Article 19 of the LCU [1]. The scientific literature under the concept of land category treats it "as part of the land fund of Ukraine, which is characterized by the main purpose and features of the legal regime" [2]. 
The definition of agricultural lands and the procedure for their use are set out in Article 22, paragraph 1 of the LCU, as "lands granted for agricultural production, agricultural research and training activities, placement of appropriate industrial infrastructure, including infrastructure of wholesale markets for agricultural products, or designed for these purposes" [1].

From the above definition, we can conclude that this is the main purpose for agricultural land. Similar definitions of the main purpose of land categories are defined in the GCC articles.

The establishment and alteration of the purpose of the land plot is defined in Article 20 of the Civil Code. According to claim 5. of this article the type of land use is derived from the intended purpose. The list of uses of agricultural land is set out in Articles 31, 33-37, which include: agricultural land, personal agricultural land, hay and pasture land, gardening land, gardening land [1]. However, this list of land use and purpose for agricultural purposes is not complete, in particular, for the characterization of economic land use in agricultural research and education.

According to Article 116 of the LCU, when transferring land parcels free of charge to the property of citizens within the limits of the norms, it is carried out once for each use [1]. That is, the norms of free transfer of land are the types of use of different basic land uses. From this we can conclude that the type of use is a characteristic of the economic use of a particular land plot and they are different for each of the main land uses.

Similarly, this is confirmed by clause 16 of Article 137 of the Law on the Law "The bidder announces the lot number indicated in the information card, location, size, purpose of the land plot and possible uses of the land plot within a certain category of land, as well as the starting price of the lot" [1].

Also in Article 25 of the Law of Ukraine "On State Land Cadastre". "The land register is a document of the State Land Cadastre containing the following information about the land plot: r) purpose (land category, type of land use within a certain land category)" [3]. 
The term land use is also found in court rulings on types of economic activity, where the functional use of the land testifies to the use of the land, which is economic use of the land.

In other normative legal acts the term land use type is absent as well as its definition at the legislative level. That is, under the LCU and the Land Book under the guise of land use is treated as a purpose, consisting of a category of land, the type of land use within a certain category of land. In the Classification of Land Purposes (KVPSP), land use as a term is also absent, and the name of a specific subdivision code of a destination is interpreted as a "name" or "purpose" so as to combine the type of use that is incorrect [4]. However, the LCU clearly states that land use is a term, in particular for agricultural land it is set out in Articles 31, 33-37 of this Code.

The concept of land use should be based on the concept of term of purpose. Also, this concept should have a broader interpretation, taking into account the economic use of land. The concept of term type of land use may be based on paragraph 1.4. UCITS defining the division of land into separate types of land use, characterized by its own legal regime, ecosystem functions, types of development, types of particularly valuable objects and land use regime [4].

However, the legal regime characterizes the purpose of land, in contrast to the type of land use, which must understand the characteristics of economic use of land, taking into account its natural conditions and quality characteristics.

Therefore, the term land use should be based on the notion of a part of the land surface with established boundaries, distinguished by natural historical features, characterized by economic land use, having a closed circuit and beyond which the qualitative characteristics of land have a different economic significance.

The change of purpose of land plots is carried out on land management projects for their allotment. The type of use as a derivative of the intended purpose, in accordance with the law, must also be established on land management projects, ie documentation on land management. The legislative mechanism governing the development of land management documentation is the Law of Ukraine "On Land Management". 
According to this law, the concept of the term intended purpose of a land plot, enshrined in Article 1 - "use of a land plot for a purpose determined on the basis of documentation on land management in accordance with the procedure established by law" [5].

Land use documentation (land use documentation) as a term has its concept in accordance with Article 1 - "approved in the established order text and graphic materials, which regulate the use and protection of state, communal and private property, as well as materials of survey and exploration of land, copyright on project implementation, etc." [5].

Pursuant to Article 2 of this Law, land management provides "the distribution of land by their intended use, taking into account public, public and private interests, and provides scientific justification." That is, a change of purpose, including the type of land use, should be provided with scientific justification and be an additional section in the documentation of land management.

In addition to the lack of concept of term and list of land use types in CLVPS, it needs further elaboration. In particular, for example, the lands of land use of NAAS institutions and enterprises, the land plots of which are assigned to subsection 01.09 "for research and educational purposes" are limited in the characterization of direct land use. Functional use of NAAS establishments and enterprises has: land, experimental fields, including fields of long-term experiments, zones of organic agriculture, berries, nurseries, zones of cultivation of elite seeds and planting material, territories with especially valuable soils, objects of natural- the conservation fund, cultural heritage sites, including those included in the UNESCO Register, historical and cultural complexes, quarantine zones and economic areas of the study fields.

Of course, all these lands belong to research and educational purposes, but their economic use is different. In the case of land use by the NAAS institutions and enterprises, the addition to the UCITS of the type of land use will be as follows (Table 1). 
1. Type of land use as an example of land use by NAAS institutions and enterprises for research and educational purposes in the

Classification of Purpose of Land Purpose (CITES)

\begin{tabular}{|c|c|c|}
\hline \multicolumn{2}{|r|}{ Purpose } & \multirow{2}{*}{$\begin{array}{c}\text { Type of use of land } \\
\text { name }\end{array}$} \\
\hline subdivision & name & \\
\hline \multirow[t]{14}{*}{01.09} & \multirow{14}{*}{$\begin{array}{l}\text { For research and educational } \\
\text { purposes }\end{array}$} & - experimental fields \\
\hline & & - fields of years of experience \\
\hline & & - $\quad$ organic farming area \\
\hline & & - berries \\
\hline & & - $\quad$ nurseries \\
\hline & & - $\quad$ areas of elite seed cultivation \\
\hline & & - growing areas of planting material \\
\hline & & - $\quad$ the area under particularly valuable soils \\
\hline & & $\begin{array}{l}\text { - the territory under the objects of the nature } \\
\text { reserve fund }\end{array}$ \\
\hline & & $\begin{array}{l}\text { - the territory under the objects of cultural } \\
\text { heritage }\end{array}$ \\
\hline & & $\begin{array}{l}\text { - the territory is assigned to the UNESCO } \\
\text { register }\end{array}$ \\
\hline & & $\begin{array}{l}\text { - the territory of historical and cultural } \\
\text { complexes }\end{array}$ \\
\hline & & - quarantine zones \\
\hline & & - economic territories \\
\hline
\end{tabular}

For other industries, land use also requires refinement in the ICPS.

Having different types of land use for land use by NAAS institutions and enterprises, there is a need to carry out works on land change and their use. Land management is the only mechanism aimed at regulating land relations, rationally organizing the territory of administrative-territorial units, influencing social and industrial relations and increasing the development of productive forces. The mechanism of implementation of these measures is carried out in accordance with Article 25 of the Law of Ukraine "On Land Management" a list of types of documentation on land management [5].

As noted earlier for land use of NAAS institutions and enterprises in the distribution (redistribution) of land by types of land use, this type of documentation from land management is missing, and existing types of documentation need to be supplemented by the content section, justify the definition of land use. 
As previously justified the change of purpose, including the type of land use, should be provided with scientific justification as an additional section in the documentation on land management (Article 2 of the Law of Ukraine "On Land Management") [5].

The type of documentation on land management for agricultural land, which in its content is most suitable for the distribution (redistribution) of land by types of land use can be attributed Project Land Management, providing ecological and economic justification of crop rotation and land management [5].

In order to carry out the distribution (redistribution) of land by types of land use by the institutions and enterprises of the NAAS, this project of land management should be supplemented with a separate section as provided for in Article 2 of the Law of Ukraine "On Land Management" - scientific substantiation of the order of land distribution (redistribution) and changes of use. The key points that need to be taken into account in the new section "Scientific justification for land use change" are:

- production direction (specialization) of the enterprise;

- types and directions of economic activity;

- assessment of the natural resource potential to which they refer (natural conditions, soil fertility, ameliorative and cultural-technical condition of lands, their contours, dismemberment, relief, configuration of land masses);

- ecological and economic efficiency of land distribution (redistribution).

Thus, supplementing the content with the section "Scientific substantiation of land use change" in the project of land management, which provides ecological and economic justification of crop rotation and land management will allow the distribution (redistribution) of land by types of land use by the institutions and enterprises of NAAS and will have the following form 2) 
2. Proposals for supplementing the content with the section "Scientific substantiation of land use change" in the project of land

management, which provides ecological and economic substantiation of crop rotation and streamlining of land for the distribution

(redistribution) of land by types of land use by institutions and enterprises of the NAAS

\begin{tabular}{|c|c|c|}
\hline Structure & Contents & Composition \\
\hline & \multirow{4}{*}{$\begin{array}{l}\text { Scientific justification for } \\
\text { changing the type of land }\end{array}$} & Production direction (specialization) of the enterprise \\
\hline & & Types and directions of economic activity \\
\hline & & $\begin{array}{l}\text { Estimation of natural resource potential (natural conditions, soil fertility, reclamation and cultural state of lands, their contours, } \\
\text { dismemberment, relief, configuration of land masses) }\end{array}$ \\
\hline & & Ecological and economic efficiency of land distribution (redistribution). \\
\hline \multirow{5}{*}{ Task } & & The basis for the work \\
\hline & & Output provided by the customer \\
\hline & & Requirements for the distribution (redistribution) of land \\
\hline & & Materials that are submitted as a result of the work \\
\hline & & $\begin{array}{l}\text { List of materials issued to the contractor for the work on the distribution (redistribution) of land of land use by institutions and } \\
\text { enterprises of the NAAS by the results of its conduct }\end{array}$ \\
\hline \multirow{16}{*}{ Text } & \multirow{8}{*}{ Explanatory note } & Introduction \\
\hline & & Landscape property description \\
\hline & & Topographic-geodetic and land surveying. \\
\hline & & Project decisions on the allocation (redistribution) of land of land use by NAAS institutions and enterprises \\
\hline & & Land cadastral works on the transfer of land boundaries in nature (to the terrain). \\
\hline & & Approval and approval of land management documentation. \\
\hline & & The procedure for registration of land plots and state registration of rights to land plots. \\
\hline & & The order of storage of land management documentation. \\
\hline & \multirow{8}{*}{ Annexes } & Baseline data for the development of land management documentation \\
\hline & & Materials of geodetic surveys and land planning \\
\hline & & Research materials of soil cover of land use by NAAS institutions and enterprises \\
\hline & & Organization of the territory for the functioning of the lands of land use of NAAS institutions and enterprises \\
\hline & & Lists restrictions on land use by NAAS institutions and enterprises \\
\hline & & Materials for transfer of land boundaries to nature (to the terrain) \\
\hline & & Project documentation approval materials \\
\hline & & Additional materials \\
\hline \multirow[b]{2}{*}{ Graphically } & & Plan of the current state of use of the exploratory fields by section, lands, restrictions and special conditions of land use \\
\hline & & $\begin{array}{l}\text { Plan for the organization of land management, the location of industrial buildings and structures, objects of engineering and social } \\
\text { infrastructure and land protection measures. }\end{array}$ \\
\hline
\end{tabular}


Conclusions and suggestions. Unregulated issues in the classification of concepts of category, purpose, type of use of their legal regime lead to the accumulation of information, which negatively affects the management decisions in land resources.

The special status of land use by institutions and enterprises of the National Academy of Agrarian Sciences of Ukraine (NAAS) requires special approaches for the implementation of land management in these land plots. In this regard, it is necessary to supplement the existing Classification of Specific Purpose of Land (CLVPS) with the use of land for research and educational purposes. In order to implement land management measures for the distribution (redistribution) of land by types of land use by NAAS institutions and enterprises, it is necessary to supplement the content of the land management project that provides ecological and economic justification for crop rotation and land management, as provided by Article 2 of the Law of Ukraine "On Land Management" scientific substantiation of the change in the type of land use. It is also necessary to regulate at the legislative level the concept of term type of land use and its logical connection in the structure of land resources between land category and purpose.

Further research needs to be done on other types of land use, such as land use, by category: forest, water, industrial, transport, defense, communications, energy, recreational, health and other uses.

\section{References}

1. Zemelnyi kodeks Ukrainy. Redaktsiia vid 13.02.2020 r. Rezhym dostupu: https://zakon.rada.gov.ua/laws/show/2768-14

2. Osnovy derzhavy i prava Ukrainy. Pidruchnyk dlia VNZ. Zatverdzheno MON. Za red. V.L. Ortynskoho. - K., 2008. - s. 583.

3. Zakon Ukrainy Pro Derzhavnyi zemelnyi kadastr 16.01.2020 r. Rezhym dostupu: https://zakon.rada.gov.ua/laws/show/3613-17

4. Pro zatverdzhennia Klasyfikatsii vydiv tsilovoho pryznachennia zemel. Nakaz Derzhavnoho komitetu Ukrainy iz zemelnykh resursiv. Redaktsiia vid 
11.07.2017 r. [Elektronnyi resurs]. Rezhym dostupu: https://zakon.rada.gov.ua/laws/show/z1011-10

5. Zakon Ukrainy «Pro zemleustrii». Redaktsiia vid 20.10.2019 r. Rezhym dostupu: https://zakon.rada.gov.ua/laws/show/858-15

Дорош Й.М., Дорош О.С., Харитоненко Р.А., Дорош А.Й., Застулка О.Ю.

НАУКОВО-МЕТОДИЧНІ ЗАСАДИ РОЗПОДІЛУ (ПЕРЕРОЗПОДІЛУ) ЗЕМЕЛЬ ЗА ЦІЛЬОВИМ ПРИЗНАЧЕННЯМ ТА ВИДАМИ ВИКОРИСТАННЯ

Проаналізовано нормативно-правові акти та наукові публікащії щодо проведення розподілу (перерозподілу) земель за цільовим призначенням та видами використання на прикладі землекористувань установ та підприємств Національної академії аграрних наук Украӥни (далі - НААН). Встановлено, щуо в чинному законодавстві відсутній вид документащії із землеустрою, щодо вирімення питань розподілу (перерозподіл) земель за видами використання. Враховувати специфіку використання земель землекористувань установ та підприємств НААН, що мають у своєму складі земельні ділянки, дослідні поля, розсадники, цінні землі для ведення наукових досліджень ,що необхідно враховувати при розробленні документаиії із землеустрою.

Обгрунтовано необхідність запровадження наукового обтрунтування щуодо визначення цільового призначення та виду використання, як розділу в документації із землеустрою Запропоновано структуру, зміст та склад документації із землеустрою де запропоновано розділ основних положень розподілу (перерозподілу) земель за видами використання в системі землекористувань установ та підприємств НААН.

Ключові слова: землеустрій, наукове обтрунтування, розподіл (перерозподіл) земель, науково-дослідне землекористування. 
Дорош И.М., Дорош О.С., Харитоненко Р.А., Дорош А.И., Застулка А.Ю.

\section{НАУЧНО-МЕТОДИЧЕСКИЕ ОСНОВЫ РАСПРЕДЕЛЕНИЯ (ПЕРЕРАСПРЕДЕЛЕНИЕ) ЗЕМЕЛЬ ПО ЦЕЛЕВОМУ НАЗНАЧЕНИЮ И ВИДАМ ИСПОЛЬЗОВАНИЯ}

Проанализированы нормативно-правовые акты и научные публикации о проведении распределения (перераспределения) земель по целевому назначению u видам использования на примере землепользования учреждений $u$ предприятий Наџиональной академии аграрных наук Украины (далее - НААН). Установлено, что в действующем законодательстве отсутствует вид документации по землеустройству, по решению вопросов распределения (перераспределение) земель по видам использования. Учитывать специфику использования земель землепользования учреждений и предприятий НАAН, имеющих в своем составе земельные участки, опытные поля, питомники, ценные земли для ведения научных исследований, что необходимо учитывать при разработке документации по землеустройству.

Обоснована необходимость введения научного обоснования по определению целевого назначения и вида использования, как раздела в документации по землеустройству Предложена структура, содержание и состав документации по землеустройству где представлены раздел основных положений распределения (перераспределения) земель по видам использования 6 системе землепользования учреждений и предприятий НААН.

Ключевые слова: землеустройство, научное обоснование, распределение (перераспределение) земель, научно-исследовательское землепользования. 